\title{
“The Great Starlit Vault Of Heaven”: Walt Whitman's Treatment of Death Through Astronomy
}

\section{Damon Pham}

\author{
Faculty Mentor: Dr. Christoph Irmscher, Department of English Indiana University
}

\section{ABSTRACT}

Death, or more accurately the defiance of death, is a recurring theme in Walt Whitman's poetry. It is also an elusive one: though he consistently asserts humankind's immortality, Whitman never arrives at a final treatment of death, instead allowing both his disposition toward death and the basis for his beliefs to be continually informed by his experiences. In this paper, I seek to better understand the metamorphosis of Whitman's faith in immortality by exploring his use of astronomical imagery. He repeatedly calls upon stars, planets, and the night sky when discussing death, and his use of these motifs varies considerably throughout his career. To observe how the overlap between death and astronomy changes over time, I analyze poetry from three editions of Leaves of Grass: the first (1855), the edition published after the Civil War (1867), and the last (1891-1892). In doing so, I show that while Whitman initially found validation for immortality through external sublimity, this validation eventually collapses upon itself, leading him to discover an even more intense (yet still indefinite) proof within his own, internal poetic intuition.

KEYWORDS: Walt Whitman, Leaves of Grass, death, astronomy

\section{INTRODUCTION}

${ }^{66}$ reat is life... and real and mystical... wherever and

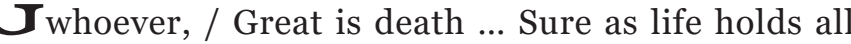
parts together, death holds all parts together; / Sure as the stars return again after they merge in the light, death is great as life." These are Walt Whitman's parting words to the reader in the 1855 edition of Leaves of Grass, his first collection of poems published and later updated throughout his life. Whitman's poetry has spanned generations and touched countless readers, including the painter of The Starry Night, Vincent van Gogh. In an 1888 letter to his sister-from which a quotation is used as the title of this paper-van Gogh describes his fascination with Whitman's poetry. ${ }^{1}$ Interestingly, it is suspected that this very fascination inspired van Gogh's famous cosmic painting. ${ }^{2}$

To someone familiar with Whitman's work, this might not be much of a surprise. Scattered throughout Leaves of Grass are images of stars, galaxies, "kosmos," and the night. In particular, Whitman often uses astronomy to express his assured faith in immortality, at least in the first edition. As Whitman's conviction becomes disfigured by post-Civil War disillusionment and later redeemed by old age, subsequent editions of Leaves of Grass offer a very different treatment of death through astronomy.

A concession: Whitman's poetry is large, contains multitudes, and is at times contradictory. ${ }^{3}$ It would be misguided to string a wholly unifying thread through its different editions, or even within a single edition, regarding a subject as expansive as death. Harold Aspiz, author of

${ }^{1}$ Vincent van Gogh, The Complete Letters of Vincent Van Gogh, Volume Three (Boston: New York Graphic Society, 1981): 445.

2 Jean Schwind, "Van Gogh's 'Starry Night' and Whitman: A Study in Source," Walt Whitman Quarterly Review 3 (1985): 1-15.

${ }^{3}$ According to Whitman himself: "Do I contradict myself? / Very well then... I contradict myself; I am large... I contain multitudes" (Whitman 2007, 67).
So Long! Walt Whitman's Poetry of Death, explains that Whitman "never develops an overarching or consistent theory of death." ${ }^{4}$ Like all humans, he was subjected to a "limited ability to grasp cosmic truths... thus the shifting strategies in the treatment of death."

Despite this ambiguity, I believe Whitman's poetry contains an important connection between death and astronomy, one that has not yet been fully examined. In this paper, I seek to better understand Whitman's evolving faith in immortality by exploring the connections between the changing treatment of astronomy in his work and his representation of death. I begin with the first edition of Leaves of Grass, proceed to the edition published after the Civil War, and end with the "deathbed" edition. By comparing the shifts in his use of astronomical imagery over the course of time, I illustrate how Whitman's initial belief in immortality is transformed by his encounters with the deaths of his fellow Americans and, eventually, the imminence of his own departure.

\section{AUTHORITY AND DUALITY IN THE FIRST EDITION}

Whitman was thirty-five years old when he published the first edition of Leaves of Grass in $1855 .^{6}$ In it, he envisions a new American philosophy, one that affirms both the grandeur and persistence of the human spirit. His philosophy was informed by a number of influences: his Quaker upbringing; his father's bold, democratic principles;

\footnotetext{
${ }^{4}$ Harold Aspiz, So Long!: Walt Whitman's Poetry of Death (Tuscaloosa: University of Alabama, 2004), 3-4.

${ }^{5}$ Ibid., 3-4.

${ }^{6}$ John Townsend Trowbridge, "Reminiscences of Walt Whitman," The Atlantic Monthly (February, 1902): 163-75.
} 
scientific knowledge; Eastern mysticism; and, most importantly, Ralph Waldo Emerson's Transcendentalist essays. ${ }^{7}$ In particular, Emerson's idea of the Over-Soul, a single, spiritual entity through which humans are interconnected, provides the backbone for Whitman's understanding of a spiritual immortality.

More remarkable than the eclecticism of these influences is the fact that none are directly credited in Leaves of Grass. There are only allusions or reflections of these influences in the poetry's style and message. Though he drew from numerous sources, Whitman sought to present his own, singular vision of America, one without a basis in past institutions. ${ }^{8}$ He renounces blind conformity to institutional authority, instead encouraging the reader to "transcend" society and seek out the truth themselves. His vision was also distinguished from those of other Transcendentalists by an emphasis on earthliness, a "passion for his native soil" in both the national and physical sense. ${ }^{9}$ Leaves of Grass is so self-contained that some scholars have gone as far as claiming its poems are "parts of a coherent religious myth."10

Whether or not this is true, two important questions arise. The first: How does Whitman manage to convince the reader of his radical ideas on immortality without the authority of a spiritual institution (or empirical evidence) at his disposal? The second: How does Whitman reconcile earthliness with the overarching grandeur of his poetry, particularly his understanding of spiritual immortality? The answers to both lie in his repeated use of astronomical imagery.

In one way, the authority of astronomical bodies is derived from their mysteriousness and sublimity. Whitman equates immortality to a planet's orbit, saying "To me the converging objects of the universe perpetually flow, / ... And I know I am deathless. / I know this orbit of mine cannot be swept by a carpenter's compass."11 Planets are too distant and too large to be fully comprehended by humankind; similarly, we are unable to completely grasp the nature of our deathlessness. Through this metaphor, Whitman not only asserts humankind's immortality, but also justifies his omission of an "overarching or consistent theory of death" by pointing out the impossibility of such an undertaking. He expands upon this metaphor in another passage as well:

"I open my scuttle at night and see the far-sprinkled systems, And all I see, multiplied as high as I can cipher, edge but the rim

${ }^{7}$ Trowbridge, "Reminiscences of Walt Whitman," 163-75; Larry $\mathrm{J}$ Reynolds, European Revolutions and the American Literary Renaissance (New Haven: Yale University Press, 1988), 126; Joseph Beaver, Walt Whitman, Poet of Science (New York: King's Crown Press, 1951); Nathaniel Preston, "Walt Whitman's Use of Indian Sources: A Reconsideration," The Ritsummeikan Bungaku 627 (2012): 4.

${ }^{8}$ Preston, "Walt Whitman's Use of Indian Sources: A Reconsideration," 1.

${ }^{9}$ Larry J Reynolds and Tibbie E. Lynch, "Sense and Transcendence in Emerson, Thoreau, and Whitman," The South Central Bulletin 39, no. 4 (1979): 148; Walt Whitman, Leaves of Grass: The Original 1855 Edition (Mineola: Dover Publications, 2007): v.

${ }^{10}$ David Kuebrich, Minor Prophecy: Walt Whitman's New American Religion (Bloomington: Indiana University Press, 1989): 4.

${ }^{11}$ Whitman, Leaves of Grass, 35. of the farther systems.

Wider and wider they spread, expanding and always expanding, Outward and outward and forever outward.

My sun has his sun, and round him obediently wheels, He joins with his partners a group of superior circuit, [...] There is no stoppage, and never can be stoppage; [...]

I tramp a perpetual journey, ${ }^{12}$

While it is interesting to note Whitman's description of an expanding universe predates its 1929 scientific discovery by Edwin Hubble, ${ }^{13}$ Leaves of Grass was written well after the acceptance of Kepler's and Newton's mechanical laws, ${ }^{14}$ so his audience would have understood the connection between the continuity of planetary motion and humankind's immortality. Moreover, their reliance on accepted scientific knowledge for visualizing the astronomical imagery, instead of their own immediate observation, parallels the leap of faith necessary for accepting Whitman's claim of immortality. He challenges his readers: "Did you guess the celestial laws are yet to be worked over and rectified?"15 Here, "celestial" takes on a dual meaning, referring to both the spiritual and the astronomical. Readers must trust the poet's authority to describe spiritual truth as they trust the physicist's authority to describe astronomical truth.

A second way astronomical imagery creates authority is through close interactions with religion. Specifically, Whitman extracts authority from religious institutions by placing religious allusion alongside astronomical imagery. One example is this passage featuring references to the realms of afterlife from Christian and Ancient Greek traditions:

My feet strike an apex of the apices of the stairs, [...]

All below duly traveled-and still I mount and mount.

Rise after rise bow the phantoms behind me, [...]

Cycles ferried my cradle, rowing and rowing like cheerful boatmen;

For room to me stars kept aside in their own rings,

They sent influences to look after what was to hold me. ${ }^{16}$

Whitman merges the Christian "stairway to heaven" with imagery reminiscent of Charon, the boatman of the Greek underworld. These religious undertones are followed by "stars kept aside in their own rings," causing the authority of religion to diffuse into the astronomical imagery. Whitman can then pursue this connotation throughout

\section{${ }^{12}$ Ibid., 62-63.}

${ }^{13}$ Edwin Hubble, "A Relation between Distance and Radial Velocity among Extra-Galactic Nebulae," Proceedings of the National Academy of Sciences of the United States of America 15, no. 3 (1929): 168-73.

${ }^{14}$ Gerald James Holton, and Stephen G. Brush, Physics, the Human Adventure: From Copernicus to Einstein and beyond (New Brunswick: Rutgers University Press, 2001): 40-46, 131-136.

${ }^{15}$ Whitman, Leaves of Grass, 37.

${ }^{16}$ Ibid., 61. 
his text, lending authority to the surrounding stanzas without referencing religion at all. This is exemplified in his self-declaration "Walt Whitman, an American, one of the roughs, a kosmos." ${ }^{17}$ He goes on to describe himself in a coarse, earthly fashion that would have turned most readers away if not counterpointed by his use of the single word "kosmos." Along with being a scientific reference to Humboldt's encyclopedic book, ${ }^{18}$ "kosmos," without being itself a religious allusion, surrounds Whitman with an aura of quasi-religious power. Through astronomy, Whitman gains credibility without becoming an institution, relating back to his desire to present a singular vision.

Whitman's self-characterization as a "kosmos" is also an example of a separate phenomenon in Whitman's poetry: the intertwining of natural and astronomical imagery in order to describe the dual nature of immortality. Whitman uses natural imagery, often in the form of plant life, to represent physical immortality. He sees grass as "the beautiful uncut hair of graves," 19 "the smallest sprout" as an indication of immortality, ${ }^{20}$ a corpse as "good manure," ${ }^{21}$ and the grave of a dead soldier as growing "seed for freedom... in its turn to bear seed." ${ }^{22}$ By relating death to these modest symbols of life, he depicts physical rebirth as benign and universal. Whitman then contrasts physical immortality with spiritual immortality by the direct juxtaposition of natural and astronomical imagery. He hears voices "of the threads that connect the stars-and of wombs, and of the fatherstuff," concluding that "copulation is no more rank to me than death is." ${ }^{33} \mathrm{He}$ senses the "generations" guiding his "embryo," for which "the nebula cohered to an orb." ${ }^{24}$ Finally, he listens to the whispering of "O stars of heaven, / O suns... O grass of graves... O perpetual transfers and promotions." ${ }^{25}$ Each of the preceding examples have astronomical imagery entangled with the natural: stars, wombs, and "fatherstuff"; an embryo and a nebula; stars of heaven and grass of graves. What stands out is the difference in familiarity. The natural imagery relates to observations the reader can find in his or her backyard; the astronomical imagery is unreachable and unfathomable. Suzan Setzer singles out the line, "I believe a leaf of grass is no less than the journey-work of the stars," ${ }^{26}$ commenting that readers must feel "how the one is an expression of the other, thus taking in the entire process of creation in one sentence." ${ }^{27}$ Through all these pairings, Whitman is saying

\footnotetext{
${ }^{17}$ Ibid., 38.

${ }^{18}$ Alexander von Humboldt, Kosmos (Stuttgart, Germany: Cotta, 1845).

${ }^{19}$ Whitman, Leaves of Grass, 24.

${ }^{20}$ Ibid., 25.

${ }^{21}$ Ibid., 66 .

${ }^{22}$ Ibid., 104.

${ }^{23}$ Ibid., 39.

${ }^{24}$ Ibid., 62.

${ }^{25}$ Ibid., 66

${ }^{26}$ Setzer, "Whitman, Transcendentalism, and the American Dream," 41. ${ }^{27}$ Ibid., 32.
}

that spiritual immortality should be as immediately obvious as the physical immortality apparent in nature. The dead remain connected to the living, in the form of the manure that nourishes the sprout and as the threads which connect the stars, our guiding ancestors.

In the first edition of Leaves of Grass, Whitman crafts a character of himself who is all-encompassing, at once looking down from the heavens, through the eyes of the American people, and up between the leaves of grass at their feet. His poetry constructs these parts as a whole, an infinite procession "with measured and beautiful motion." ${ }^{28}$ Through astronomical imagery, Whitman is able to transcend limitations of time and space, to exist among the immortal planets and stars.

\section{THE AFTERMATH OF THE CIVIL WAR}

Whitman's affirmation of immortality, expressed with confidence in the first edition, becomes remarkably more conservative in his poetry following the Civil War. As a volunteer nurse, he was a direct witness to the Civil War's carnage, an experience that led him to question the extent to which a poetic belief in immortality comforted the loss of human life. ${ }^{29}$ The changes in his perception of death are evident in two poems first added to Leaves of Grass in the 1867 edition: "When Lilacs Last in the Dooryard Bloom'd," an elegy for the assassinated President Lincoln, and "Vigil Strange I Kept on the Field One Night." ${ }^{30}$ In both of these poems, the poet remains grounded by his earthly existence, looking up into a night sky unreflective of human grief and impermanence.

Central to "Lilacs" is a trio of images: lilac, bird, and star. While Whitman's previous poetry depicts astronomical bodies as vast and untouchable, the star in "Lilacs," used to personify Lincoln, is much different. Though "great" and "powerful," it "early droop'd in the western sky" and is hidden by a "black murk." 3132 The star closely interacts with him, wandering by his side until it is "lost in the netherward black of the night" and detaining him - in other words, lingering in his thoughts. ${ }^{33}$ In contrast, the other stars continue their cyclical procession uninhibited.

The singularity of Lincoln's star in "Lilacs" reflects the poet's confinement within himself. Whitman no longer speaks with an all-encompassing voice, and is instead encompassed himself by the spirit of death. Just as the star is separated

\footnotetext{
${ }^{28}$ Whitman, Leaves of Grass, 95.

${ }^{29}$ Aspiz, So Long!, 161.

${ }^{30}$ Walt Whitman, Leaves of Grass, 4th ed. (New York: Wm. E. Chapin \& Co., 1867): xl-xli, xvii.

${ }^{31}$ The 1867 edition of Leaves of Grass consists of four parts, each with their own page numbering: Leaves of Grass, Drum Taps, Sequel to Drum Taps, and Songs Before Parting. To avoid confusion, I appended "a," "b," and "c" to page number citations for Drum Taps, Sequel to Drum Taps, and Songs Before Parting, respectively.

${ }^{32}$ Ibid., 3b.

${ }^{33}$ Ibid., 6b.
} 
from the greater universe by a "black murk," Whitman's soul is made "helpless" by "cruel hands" and a "harsh surrounding cloud"; the Earth is enveloped by the "coming eve." 34 This does not mean Whitman retracts his claims for immortality; at the end of the poem, night becomes day and the poet leaves the lilac untouched, "blooming, returning with spring." 35 He also does not condemn death, instead beckoning it to "undulate round the world, serenely arriving, arriving." 36 What is different is that he speaks from a personal, rather than global, perspective. Unable to see past the horizon, Whitman no longer places death within the context of a greater, infinite procession.

The disconnection between astronomical movement and human life is also apparent in "Vigil Strange I Kept on the Field One Night." ${ }^{37}$ In this poem, the poet returns to a fallen comrade to discover he has died. The dead boy has "bared [his] face in the starlight," his still face unreflective of the rotating heavens he looks upon. During the poet's vigil, "as onward silently stars aloft, eastward new ones upward stole." As in "Lilacs," the stars continue their procession indifferently, and while the poet recognizes the "sweet hours, immortal and mystic hours" spent with his comrade, he nonetheless is left in grief.

In the first edition of Leaves of Grass, Whitman uses astronomy to create authority and to illustrate the duality of body and soul. In "Lilacs" and "Vigil," authority instead comes from the authenticity of the poet's own grief. Moreover, though Whitman still intertwines the natural with the astronomical, he severs the connection between life and death for both. In "Lilacs," he does not follow up on the metaphor of Lincoln's star to comment on how the star will rejoin the others, thus returning the next night. Similarly, the vibrant, natural imagery of a "gorgeous, indolent, sinking sun," "fresh sweet herbage," and the "breast of the river" only contrast with the soldiers who lie dead on the battlefield. ${ }^{38}$ Whitman is silent about their return to the natural world. The living and dead occupy different spheres, both spiritually and physically.

\section{WHITMAN'S PARTING THOUGHTS}

Whitman went on to live for more than twenty years after the Civil War. This left time for him to accept the losses of the war, and time to come to terms with his own ailing health. He

\footnotetext{
${ }^{34}$ Ibid., 38.

${ }^{35}$ Alexander von Humboldt, Kosmos (Stuttgart, Germany: Cotta, 1845).

${ }^{36}$ Whitman, Leaves of Grass, 24.

${ }^{37}$ Ibid., 25 ,

${ }^{38}$ Ibid., 66.
}

never ceased writing, publishing the final, enormous edition of Leaves of Grass (the "deathbed" edition) in 1892, the same year of his death. I chose two pairs of poems from this final edition to analyze based on their dialectical relationships. "On the Beach at Night Alone" and "On the Beach at Night" are intended to be read together, evidenced by their similar titles, similar content, and Whitman's placement of them close to each other. ${ }^{39}$ "Alone" was first published in 1856 under the title "Clef Poem," and "Night" in 1871.40 "Grand is the Seen" and "Unseen Buds" constitute the other pair; they were both first published in 1891 and placed adjacently toward the end.$^{41}$ In temporal order, these poems seem to summarize Whitman's evolving relationship with death.

Much like poetry from the first edition, "On the Beach at Night Alone" presents an all-encompassing, almost simplistic view of immortality. The poet refers to a "vast similitude [that] interlocks all," one that "shall forever span them and compactly hold and enclose them." 42 He uses astronomy to create a sense of authority, universality, and sublimity. In this way, "On the Beach at Night" readily serves as its foil. Here, the poet is now with a child, and is soothing her fear of the black clouds covering the stars. He tells her that the stars shall soon emerge, and that they are "immortal"; however, he does not seem to be honest, as he later ponders the burial of the "delicate" Pleiades. ${ }^{43}$ This is surprising: Whitman's earlier poetry connected astronomical cycles to human immortality. His postwar poetry questioned the extent of that connection. Now, Whitman claims that the stars themselves are fallible. Instead, he sees something in humans "more immortal even than the stars." ${ }^{44}$ But what?

At first thought, the answer might be the human soul. That is certainly Whitman's reply in "Grand is the Seen": "Grand is the earth, and grand are lasting time and space, / ... But grander far the unseen soul of me, comprehending, endowing all of those /... More multiform far-more lasting thou than they." ${ }^{45}$ However, this is clearly not his full response; the poem immediately following, "Unseen Buds," is a pivotal addendum. Whitman describes "unseen buds, infinite, hidden well, / ... Like babes in wombs... (On earth and in the sea-the universe -the stars there in the heavens,) / Urging slowly, surely forward, forming endless, / And waiting ever more, forever more behind." ${ }^{46}$ By transforming bud to star, he places the

\footnotetext{
${ }^{39}$ A. James Wohlpart, "From the Material to the Spiritual in the Sea-Drift Cluster: Transcendence in 'On the Beach at Night,' 'The World below the Brine,' and 'On the Beach at Night Alone," Walt Whitman Quarterly Review 13 (1996): 150.

${ }^{40}$ Walt Whitman, Leaves of Grass: A Textual Variorum of the Printed Poems, 3 vols, ed. Sculley Bradley (New York: New York University Press, 1980): xxxvi, xlii, 241.

${ }^{41}$ Ibid., xlvi.

${ }^{42}$ Walt Whitman, Leaves of Grass 9th ed. (Philadelphia: David McKay, 1891-1892): 207.

${ }^{43}$ Ibid., 206.

${ }^{44}$ Ibid.

${ }^{45}$ Ibid., 421.

${ }^{46}$ Ibid.
} 
procreant and "unseen" force of immortality into the heavens. Immortality becomes an Over-Soul-like entity, too complex and universal to be delineated to the human soul. Perhaps this is the final function of astronomy in Whitman's work. As the last frontier for humankind, it is the keeping place for our greatest secret. For Whitman, recognizing the safe-keeping of human immortality is enough; he does not feel the need to uncover it and reveal its contents.

\section{CONCLUSION}

A look at the skies has been traditionally associated with thoughts of eternity or even death, and Whitman's use of astronomical imagery is no exception. Like many humans before him, he sought to thread the vast array of lights in the heavens into meaningful constellations. In his earlier work, he appeared to do so by transcending mortal limitations through astronomical imagery. Later, he instead used astronomy to enhance the elusive shroud of death. While Whitman may have initially held claim to a universal proof for immortality, I believe during the final years of his life he arrived at a more personal understanding of immortality. The "proof" became his own poetry in and of itself, a domain that extends past Earth and sky, encompassing even astronomical bodies and, with them, the mystery of human immortality.

\section{AUTHOR INFORMATION}

All correspondence should be sent to the first author: ddpham@iu.edu.

\section{BIBLIOGRAPHY}

Aspiz, Harold. So Long!: Walt Whitman's Poetry of Death. Tuscaloosa: University of Alabama, 2004.

Beaver, Joseph. Walt Whitman, Poet of Science. New York: King's Crown Press, 1951.

Holton, Gerald James, and Stephen G. Brush. Physics, the Human Adventure: From Copernicus to Einstein and beyond. New Brunswick: Rutgers University Press, 2001.

Hubble, Edwin. "A Relation between Distance and Radial Velocity among Extra-Galactic Nebulae.” Proceedings of the National Academy of Sciences of the United States of America 15, no. 3 (1929): 168-73.

Humboldt, Alexander von. Kosmos. Stuttgart, Germany: Cotta, 1845.

Kuebrich, David. Minor Prophecy: Walt Whitman's New American Religion. Bloomington: Indiana University Press, 1989.

Preston, Nathaniel. "Walt Whitman's Use of Indian Sources: A Reconsideration." The Ritsummeikan Bungaku 627 (2012): 1-12.
Reynolds, Larry J. European Revolutions and the American Literary Renaissance. New Haven: Yale University Press, 1988.

Reynolds, Larry J and Tibbie E. Lynch. "Sense and Transcendence in Emerson, Thoreau, and Whitman." The South Central Bulletin 39, no. 4 (1979): 148-51.

Schwind, Jean. "Van Gogh's 'Starry Night' and Whitman: A Study in Source." Walt Whitman Quarterly Review 3 (1985): 1-15.

Setzer, Suzan. "Whitman, Transcendentalism and the American Dream: Alliance with Nature's Government through Language." Modern Science and Vedic Science 9, no. 1 (1999): 2-48.

Trowbridge, John Townsend. "Reminiscences of Walt Whitman.” The Atlantic Monthly, February, 1902, 163-75.

Van Gogh, Vincent. The Complete Letters of Vincent Van Gogh, Volume Three. Boston: New York Graphic Society, 1981.

Whitman, Walt. Leaves of Grass. 2nd ed. Brooklyn: Fowler \& Wells, 1856.

Whitman, Walt. Leaves of Grass. 4th ed. New York: Wm. E. Chapin \& Co., 1867.

Whitman, Walt. Leaves of Grass. 9th ed. Philadelphia: David McKay, 1891-1892.

Whitman, Walt. Leaves of Grass: A Textual Variorum of the Printed Poems, 3 vols. Edited by Sculley Bradley. New York: New York University Press, 1980.

Whitman, Walt. Leaves of Grass: The Original 1855 Edition. Mineola: Dover Publications, 2007.

Wohlpart, A. James. "From the Material to the Spiritual in the Sea-Drift Cluster: Transcendence in 'On the Beach at Night,' 'The World below the Brine,' and 'On the Beach at Night Alone." Walt Whitman Quarterly Review 13 (1996): 149-158. 
